University of Nebraska - Lincoln

DigitalCommons@University of Nebraska - Lincoln

Publications of the US Geological Survey

US Geological Survey

4-2009

Northern Prairie Wildlife Research Center

Follow this and additional works at: https://digitalcommons.unl.edu/usgspubs

Part of the Earth Sciences Commons

"Northern Prairie Wildlife Research Center" (2009). Publications of the US Geological Survey. 31.

https://digitalcommons.unl.edu/usgspubs/31

This Article is brought to you for free and open access by the US Geological Survey at DigitalCommons@University of Nebraska - Lincoln. It has been accepted for inclusion in Publications of the US Geological Survey by an authorized administrator of DigitalCommons@University of Nebraska - Lincoln. 


\section{Northern Prairie Wildlife Research Center}

\section{Integrated Science for the Nation's Northern Great Plains}

The Northern Prairie Wildlife Research Center (NPWRC) conducts integrated research to fulfill the Department of the Interior's responsibilities to the Nation's natural resources. Located on 600 acres along the James River Valley near Jamestown, North Dakota, the NPWRC develops and disseminates scientific information needed to understand, conserve, and wisely manage the Nation's biological resources. Research emphasis is primarily on midcontinental plant and animal species and ecosystems of the United States.

During the center's 40-year history, its scientists have earned an international reputation for leadership and expertise on the biology of waterfowl and grassland birds, wetland ecology and classification, mammalian behavior and ecology, grassland ecosystems, and application of statistics and geographic information systems.

To address current science challenges, NPWRC scientists collaborate with researchers from other U.S. Geological Survey centers and disciplines (Biology, Geography, Geology, and Water) and with biologists and managers in the Department of the Interior (DOI), other Federal agencies, State agencies, universities, and nongovernmental organizations. Expanding upon its scientific expertise and leadership, the NPWRC is moving in new directions, including invasive plant species, restoration of native habitats, carbon sequestration and marketing, and ungulate management on DOI lands.

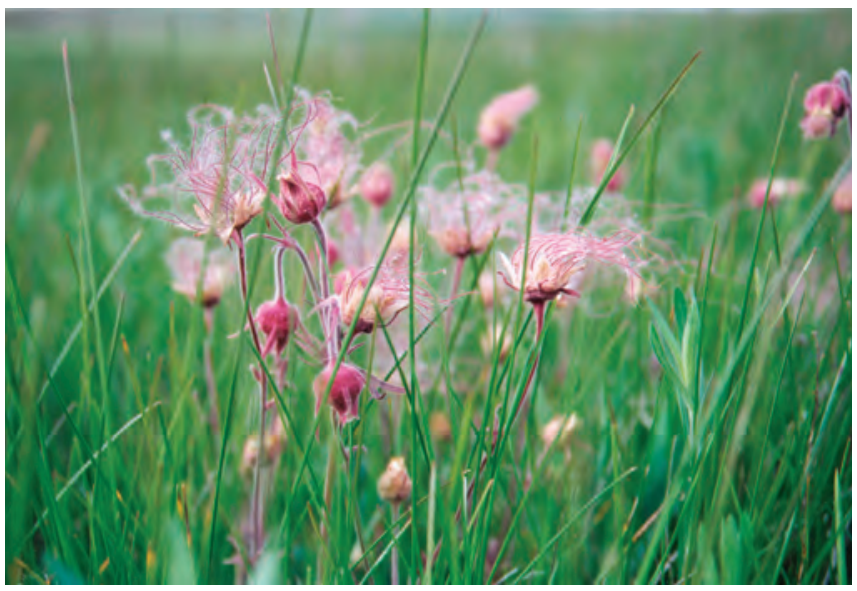

Prairie Smoke (Geum triflorum)

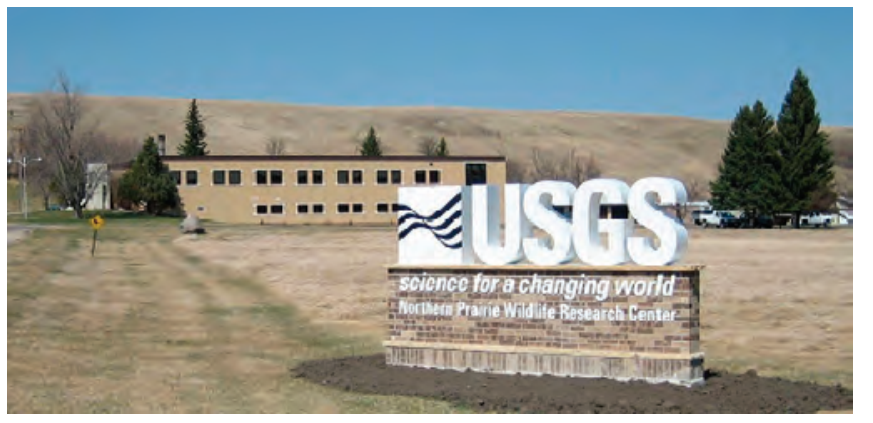

\section{Core Science Capabilities}

Grounded in long-term and geographically extensive efforts, NPWRC research provides scientific understanding to support issues such as:

- Land management: sedimentation, fire ecology, invasive exotic plant species, restoration of grasslands and wetlands.

$\checkmark$ Land use changes: particularly habitat loss and fragmentation.

$\checkmark$ Climate change and human effects on native plants and animals and their habitat: effects of intensive grazing, modified predator communities, carbon sequestration of wetlands and prairie ecosystems, and altered river flows, such as in the Missouri River and Platte River.

- Terrestrial biology: particularly biology of waterfowl, migratory birds, and mammalian predators.

\section{Center Expertise}

The expertise and experience of NPWRC's research staff has positioned the center to respond to emerging issues and to challenges that require long-term study:

$\checkmark$ Assess native communities and populations.

$\checkmark$ Develop quantitative monitoring protocols.

Address issues affecting conservation of endangered or threatened species.

$\checkmark$ Develop and refine tools for inventory and monitoring.

Apply statistical, remote sensing, and geographical information systems to wildlife ecology. 


\section{Highlights of Current Research Program}

The strength and breadth of NPWRC's scientific expertise attracts collaborators and support for technical innovation and groundbreaking investigations. The U.S. Army Corps of Engineers, for example, presently funds extensive research efforts on the Missouri River to determine the effects of water level management on emergent sandbar habitat used by least terns and piping plovers and establish monitoring and management methods.

In partnership with the National Park Service (NPS), our researchers are developing experimental approaches to understanding and predicting the colonization, persistence, and spread of invasive plant species. Other NPS work includes research on elk population levels and movement in Theodore Roosevelt and Badlands National Parks, and work on wolf biology in northern Minnesota and in Yellowstone National Park.

The U.S. Department of Agriculture (USDA) provides significant funds for interdisciplinary scientific work of the Integrated Landscape Monitoring (ILM) project. The ILM Prairie Pilot Study has established a comprehensive monitoring strategy for integrated natural resource landscape management in the Prairie Pothole Region that also serves as a framework for a consistent national approach to monitoring and modeling.

Strengths of the NPWRC include an exemplary reputation in migratory bird (grassland birds and waterfowl) and canid (gray wolves, swift fox, and island fox) research. Work pioneered by NPWRC researchers on threatened and endangered species continues in partnership with the U.S. Fish and Wildlife Service. One such effort investigates the role of fire and habitat characteristics in the distribution and abundance of yellow rails, Le Conte's sparrows, and other birds of open and woody fens.

Another avian research project studies one of North America's most critical ecosystems for migratory waterbirdsthe Central Platte River Valley (CPRV) and the adjacent Rainwater Basin Area (RBA) in south-central Nebraska. Together these two areas form an internationally significant staging area for migratory water birds. Several million waterfowl stage for spring migration in the CPRV and RBA each year. About 80 percent of the world population of sandhill cranes stops there each spring, including all sandhill cranes that breed in Russia and most of the cranes that breed in Canada and Alaska.

The NPWRC has ongoing studies assessing the utility of Light Detection and Ranging (LiDAR) in characterizing wildlife habitat and carbon budgets in forested (Maine, Minnesota), riparian (Nebraska, Nevada), shrubland (Nevada, Wyoming), and wetland (North Dakota) ecosystems.

For more information, contact:

Director, U.S. Geological Survey

Northern Prairie Wildlife Research Center

8711 37th Street SE, Jamestown, ND 58401

Telephone: 701-253-5500

www.npwrc.usgs.gov

\section{Our Mission}

To provide and disseminate scientific information needed to conserve and manage the Nation's biological resources, with an emphasis on species and ecosystems of the Nation's interior. Specifically, the center's goals include the following:

- Evaluate responses of fauna and flora to natural and anthropogenic influences.

Develop tools for assessing status and trends of animal and plant populations.

Use integrated, long-term research to model linkages among ecosystem components.

Develop the biological knowledge needed to sustain and restore ecosystems.

Provide the scientific foundation for Federal policies and management strategies related to natural resources.

Disseminate the latest in technical information and research findings to client agencies, conservation organizations, and others responsible for the management of our Nation's natural resources.

\section{Locations of the Center and Duty Stations}

The Northern Prairie Wildlife Research Center is one of 18 science and technology centers in the Biological Resources Discipline, administratively positioned in the North Central Area of the Central Region and geographically located in the northern Great Plains. The main campus is in Jamestown, North Dakota. In addition, the center maintains duty stations in St. Paul and Ely, Minnesota, and in Hot Springs, South Dakota, to colocate research scientists with partners in the NPS, the USDA, and the University of Minnesota.

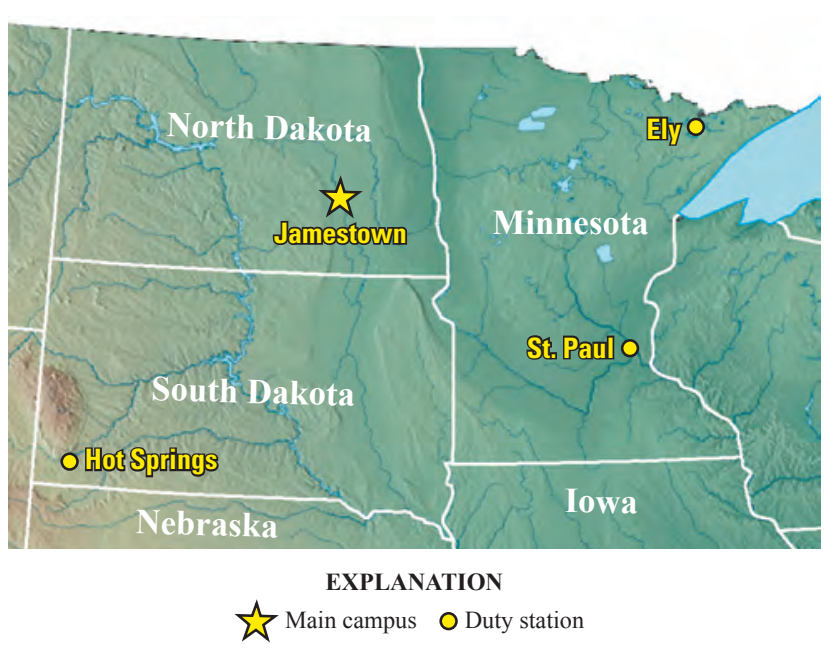

